\title{
PENGARUH MODEL PEMBELAJARAN INTEGRATIF DAN KEMAMPUAN BERPIKIR KRITIS TERHADAP HASIL BELAJAR SEJARAH SISWA SMA
}

\author{
Reni Wulandari, Sarkadi, dan Kurniawati \\ Pendidikan Sejarah Pascasarjana Universitas Negeri Jakarta \\ e-mail: reni.wulandari46@yahoo.com
}

\begin{abstract}
Abstrak
Penelitian ini bertujuan untuk mengetahui pengaruh model pembelajaran dan kemampuan berpikir kritis terhadap hasil belajar sejarah siswa di SMA Negeri 13 Bekasi. Jenis penelitian yang digunakan adalah penelitian kuantitatif dengan menggunakan metode eksperimen desain treatment by level $2 \times 2$. Populasi terdiri dari seluruh siswa kelas XI IIS. Sampel terdiri dari dua kelas yaitu kelas XI IIS 2 dan XI IIS 3 dengan jumlah 72 siswa. Instrumen yang digunakan untuk hasil belajar adalah tes pilihan ganda dan yang digunakan untuk kemampuan berpikir kritis adalah kuesioner. Hasil penelitian ini menunjukkan bahwa: 1) hasil belajar siswa yang diberikan model pembelajaran integratif lebih tinggi dari siswa yang diberikan model pembelajaran kooperatif; 2) terdapat pengaruh interaksi antara model pembelajaran dan kemampuan berpikir kritis; 3) hasil belajar sejarah siswa yang diberikan model pembelajaran integratif dan memiliki kemampuan berpikir kritis tinggi, lebih tinggi dari siswa yang diberikan model pembelajaran kooperatif dan memiliki kemampuan berpikir kritis tinggi; 4) hasil belajar sejarah siswa yang diberikan model pembelajaran integratif dan memiliki kemampuan berpikir kritis rendah, lebih rendah dari siswa yang diberikan model pembelajaran kooperatif dan memiliki kemampuan berpikir kritis rendah.
\end{abstract}

Kata Kunci: hasil belajar sejarah, model integratif, berpikir kritis

\section{THE EFFECT OF INTEGRATIVE LEARNING MODEL AND CRITICAL THINKING ABILITY TOWARD STUDENTS' HISTORICAL LEARNING OUTCOME IN SENIOR HIGH SCHOOL}

\begin{abstract}
This study aims at determining the effect of learning model and critical thinking ability toward students' historical learning outcome in State Senior High School 13 Bekasi. This study is quantitative research by using experiment method with treatment by level $2 \times 2$ design. The population of this study is all students of XI IIS class. While, the sample is chosen two classes, namely XI IIS 2 class and XI IIS 3 class with total of 72 students. The instruments used are multiple choice test to measure learning outcome and questionnaire to measure critical thinking ability. The results of this study indicated that: 1) students' learning outcome by using integrative learning model is higher than using cooperative learning model, 2) there is an interaction effect between learning model and critical thinking ability, 3) students' historical learning result using integrative learning model and having higher critical thinking ability is higher than using cooperative learning model and having higher critical thinking ability, (4) students' historical learning outcome using integrative learning model and having low critical thinking ability is lower than using cooperative learning model and having low critical thinking ability.
\end{abstract}

Keywords: history learning outcome, integrative model, critical thinking 


\section{PENDAHULUAN}

Pembelajaran adalah suatu proses interaksi siswa dengan guru dan sumber belajar dalam satu lingkungan belajar. Proses interaksi dalam pembelajaran yang efektif memudahkan siswa dalam mengolah informasi. Dalam proses pembelajaran yang diarahkan untuk mendorong siswa mencari tahu bukan pembelajaran yang memberi tahu siswa. Sebagai pendidik guru sebagai salah satu fasilitator belajar, tetapi berinteraksi dengan keseluruhan sumber belajar yang mungkin dipakai untuk mencapai kompetensi dasar dan tujuan pembelajaran. Dengan kata lain, dalam pembelajaran guru tetap membimbing siswa agar dapat belajar dengan baik serta memberikan perubahan bagi siswa. Perubahan yang terjadi bagi siswa yakni aspek kognitif, aspek afektif dan aspek psikomotorik.

Guna mencapai tujuan pembelajaran yang sesuai dengan harapan, seorang guru perlu memilih model pembelajaran yang sifatnya membangun kemampuan berpikir kritis siswa. Perubahan ini mampu mengarahkan siswa untuk memperoleh ide, keterampilan, melatih daya kritis, motivasi, serta meningkatkan hasil belajar. Mengembangkan pemikiran kritis menuntut latihan menemukan pola, menyusun penjelasan, membuat hipotesis, melakukan generalisasi, dan mengemas temuan bukti dengan matriks lalu mengkomunikasikan informasi.

Pengajaran sejarah di sekolah bertujuan agar siswa memperoleh kemampuan berpikir historis dan pemahaman sejarah. Melalui pengajaran sejarah, siswa mampu mengembangkan kompetensi untuk berpikir secara kronologis dan memiliki pengetahuan tentang masa lampau yang dapat digunakan untuk memahami dan menjelaskan proses perkembangan dan perubahan masyarakat serta keberagaman sosial budaya dalam rangka menemukan dan menumbuhkan jati diri bangsa di tengah-tengah kehidupan masyarakat dunia. Pengajaran sejarah di sekolah bertujuan agar siswa memperoleh pemahaman ilmu, memupuk berpikir kritis siswa dan pemahaman sejarah. Pemahaman ilmu membawa pemerolehan fakta dan penguasaan ide-ide dan kaedah sejarah.

Pembelajaran sejarah adalah pembelajaran yang mampu menumbuhkan kemampuan siswa melakukan konstruksi kondisi masa sekarang dengan mengkaitkan atau melihat masa lalu yang menjadi basis topik pembelajaran sejarah (Subakti, 2010). Apalagi sejarah tidak akan terlepas dari konsep waktu, kontinyuitas dan perubahan. Pembelajaran sejarah yang baik tidak terbatas pada pengetahuan faktual saja. Siswa juga dituntut untuk dapat memahami perkembangan peristiwa bersejarah secara imajinatif dan analitis. Pembelajaran sejarah merupakan alat untuk mengembangkan cara berpikir peserta didik ke dalam tatanan berpikir historis dan kemampuan kesejarahan, merekonstruksi fakta yang ditemukan menjadi suatu peristiwa sejarah. Melalui pembelajaran sejarah siswa diharapkan dapat menginterpretasi nilai-nilai sejarah bangsanya, menjadi sumber daya manusia yang bernalar tinggi, kritis, kreatif, inovatif, dan penuh percaya diri.

Dalam proses pembelajaran model integratif melalui pendekatan teori belajar konstruktivisme, tugas guru bergeser dari menyampaikan ilmu pengetahuan kepada siswa, merangsang stimulus siswa untuk menggunakan apa yang telah dimiliki baik pengetahuan maupun pengalamannya, agar dapat memahami dan menginterpretasi pengetahuan serta pengalaman belajar yang baru.

Berdasarkan observasi peneliti di SMA Negeri 13 Bekasi, kenyataan yang sering terjadi dalam proses pembelajaran sejarah berbeda sekali dengan apa yang diharapkan. Dengan guru memberikan penugasan kelompok, membuat siswa cenderung pasif dan hanya beberapa siswa saja yang mengerjakan tugasnya sehingga menjadikan pembagian tugasnya tidak merata. Hal ini terlihat bahwa siswa kurang membangun pengetahuan dan pemahaman serta tidak tertarik pada mata pelajaran sejarah karena pelajaran sejarah 
membosankan. Hal tersebut di atas, mempengaruhi hasil belajar siswa dalam mata pelajaran sejarah. Hasil belajar sejarah berada di bawah KKM karena minat dalam proses pembelajaran siswa tidak didorong untuk terciptanya pengetahuan dan pemahaman dalam berpikir kritis. Keaktifan siswa dalam menjawab pertanyaan guru sangat kurang, karena minimnya penggunaan buku teks atau sumber informasi lainnya.

Fakta lain, guru sejarah hanya memberikan informasi berupa hapalan fakta-fakta berupa urutan waktu, nama tokoh, dan peristiwa-peristiwa yang terjadi di masa lampau yang hal tersebut dirasa kurang bermakna. Sebagai contoh, proses pembelajaran sejarah membuat siswa tidak mampu menganalisis sebab-akibat peristiwa Perang Dunia I dan Perang Dunia II secara historis.

Berdasarkan paparan di atas, penelitian ini perlu dilakukan, mengingat masih banyak guru yang belum menerapkan model pembelajaran yang inovatif untuk meningkatkan hasil belajar. Salah satu model yang dirasa cukup tepat diterapkan untuk mengembangkan kemampuan berpikir kritis adalah model pembelajaran integratif. Hal ini menunjukkan bahwa penggunaan model pembelajaran integratif sebagai salah satu upaya dalam meningkatkan prestasi dan hasil belajar siswa. Pembelajaran Integratif mengacu pada keaktifan siswa dalam menyampaikan ide atau pendapatnya yang didapatkan dari permasalahan materi yang dihadapi. Dengan demikian tujuan penelitian ini adalah untuk mengetahui pengaruh model pembelajaran dan kemampuan berpikir kritis terhadap hasil belajar sejarah siswa.

\section{METODE}

Metode yang digunakan dalam penelitian ini adalah eksperimen dengan Desain Treatment by level $2 \times 2$. Penelitian ini merupakan penelitian eksperimen menggunakan satu kelas kontrol dengan model pembelajaran kooperatif dan satu kelas eksperimen dengan model pembelajaran integratif. Populasi target dalam penelitian ini adalah seluruh siswa SMA Negeri 13 Bekasi. Populasi terjangkau adalah seluruh siswa kelas XI IIS. Sampel diambil dengan menggunakan teknik random sampling, yang kemudian akan diperoleh satu kelas kontrol dan satu kelas eksperimen. Jumlah siswa yang menjadi subjek penelitian adalah 72 siswa dibagi menjadi dua kelompok masingmasing terdiri dari 30 siswa.

Sebelum diberikan perlakuan, siswa yang berada di dalam dua kelas ini diberikan kuesioner untuk mendapatkan data skor kemampuan berpikir kritis . Skor pengisian kuesioner tersebut disusun berdasarkan 3 kelompok skor tertinggi ke skor yang terendah. Setiap kelas ditetapkan $27 \%$ dari ranking teratas digolongkan sebagai kelompok siswa yang memiliki kemampuan berpikir kritis tinggi dan $27 \%$ dari ranking terbawah digolongkan sebagai kelompok siswa yang memiliki kemampuan berpikir kritis rendah, dan kemampuan berpikir kritis sedang $46 \%$ (Sugiyono, 2017).

Data yang dikumpulkan dalam penelitian ini meliputi data hasil belajar dan kemampuan berpikir kritis siswa pada mata pelajaran sejarah. Jenis instrumen yang digunakan adalah tes hasil belajar sejarah berupa tes piihan ganda dengan uji validitas menggunakan rumus Point Biserial Corelation dan uji reliabilitas menggunakan rumus KR20. Jenis instrumen kemampuan berpikir kritis berupa kuesioner dengan uji validitas menggunakan koreasi Product Moment dan reliabilitas menggunakan Alpha Cronbach.

Data yang diperoleh melalui instrumen penelitian dianalisis menggunakan analisis deskriptif dan inferensial. Analisis deskriptif dilakukan dengan penyajian tabel distribusi, histogram, rata-rata dan simpangan baku. Uji normalitas dalam penelitian ini menggunakan Uji Liliefors. Sedangkan uji homogenitas menggunakan Uji Bartlett pada taraf $\alpha=0.05$. Uji hipotesis dalam penelitian ini menggunakan uji analisis variansi (ANAVA) untuk menguji efek utama dan pengaruh interaksi antar A dan B. Pengujian dilanjutkan 
dengan menggunakan Uji Tuckey untuk melihat hasil perbandingan di antara kelompok perlakuan penelitian.

\section{HASIL DAN PEMBAHASAN Hasil}

Pengujian normalitas dilakukan dengan menggunakan Uji Liliefors pada taraf signifikansi $\alpha=0,05$ untuk kriterianya yaitu apabila $\mathrm{L}_{\text {hitung }}\left(\mathrm{L}_{0}\right)$ lebih kecil dari $\mathrm{L}_{\text {tabel }}\left(\mathrm{L}_{\mathrm{t}}\right)$, maka dapat dikatakan bahwa data hasil penelitian berdistribusi normal. Hasil perhitungan pada data hasil penelitian ini adalah sebagai berikut:

Tabel 1. Hasil Uji Normalitas (Liliefors) Hasil Belajar Sejarah

\begin{tabular}{llllrc}
\hline Klmpk & \multicolumn{1}{c}{$\boldsymbol{\alpha}$} & $\mathrm{N}$ & $\mathrm{L}_{\text {hitung }}$ & $\mathrm{L}_{\text {tabel }}$ & Ket \\
\hline A1 & & 18 & 0,142 & 0,209 & Normal \\
A2 & & 18 & 0,111 & 0,209 & Normal \\
A1B1 & 0,05 & 9 & 0,096 & 0,295 & Normal \\
A1B2 & & 9 & 0,177 & 0,295 & Normal \\
A2B1 & & 9 & 0,130 & 0,295 & Normal \\
A2B2 & & 9 & 0,188 & 0,295 & Normal \\
\hline
\end{tabular}

Tabel di atas menunjukan bahwa nilai Liliefors hasil perhitungan (Lo) untuk semua data yang lebih kecil dari Liliefors tabel (Lt), dapat disimpulkan bahwa kelompok sampel penelitian berasal dari populasi yang berdistribusi normal, sehingga persyaratan normalitas dapat terpenuhi.

Uji Homogenitas dilakukan terhadap data kombinasi perlakuan antara model pembelajaran dengan kemampuan berpikir kritis siswa $\left(\mathrm{A}_{1} \mathrm{~B}_{1}, \mathrm{~A}_{1} \mathrm{~B}_{2}, \mathrm{~A}_{2} \mathrm{~B}_{1}\right.$, dan $\left.\mathrm{A}_{2} \mathrm{~B}_{2}\right)$, pengujian normalitas dilakukan dengan cara Uji Bartlett pada taraf signifikansi $\alpha=$ 0,05, di mana dk (1-a) (k-1) dengan kriteria apabila nilai hitung lebih kecil dari nilai tabel maka varians semua kelompok bersifat homogen. Hasil perhitungan pengujian homogenitas varians kelompok kombinasi menunjukan $\mathrm{X}^{2}$ hitung yaitu 0,711 dan $X^{2}$ tabel yaitu 7,81. Dari hasil pengujian homogenitas varians dapat disimpulkan bahwa $\mathrm{H}_{0}$ diterima. Hal ini berarti tidak ada perbedaan varians dan keempat kelompok, maka data tersebut dapat disimpulkan bahwa data tersebut homogen.
Tahap pengujian terbukti bahwa data yang diperoleh merupakan data yang berasal dari sampel yang normal dan homogen. Maka selanjutnya adalah pengujian hipotesis penelitian, pengujian ini dilakukan untuk mengetahui efek utama yakni pengaruh model pembelajaran integratif dan model pembelajaran kooperatif terhadap hasil belajar sejarah, serta efek interaksi antara model pembelajaran dengan kemampuan berpikir kritis berdasarkan data hasil belajar sejarah. Pengujian hipotesis meliputi uji terhadap efek utama dan efek interaksi terhadap hasil belajar dengan menggunakan uji analisis varians dua jalur (ANAVA 2x2). Berikut merupakan hasil perhitungan analisis yang dilakukan dengan menggunakan ANAVA $2 \times 2$ :

Tabel 2. Hasil Perhitungan Analisis Varians Dua Jalur (ANAVA)

\begin{tabular}{|c|c|c|c|c|c|c|c|}
\hline \multirow{2}{*}{$\begin{array}{l}\text { Sumber } \\
\text { Variansi }\end{array}$} & \multirow{2}{*}{$\mathrm{Db}$} & \multirow{2}{*}{ JK } & \multirow{2}{*}{ RJK } & \multirow{2}{*}{\multicolumn{2}{|c|}{$F_{\text {hitung }}$}} & \multicolumn{2}{|c|}{$\mathrm{F}_{\text {tabel }}$} \\
\hline & & & & & & 0,05 & 0,01 \\
\hline Model & 1 & 87,1 & 57,7 & 7,319 & * & 4,15 & 7,50 \\
\hline $\begin{array}{l}\text { Pembelaj } \\
\operatorname{aran}(\mathrm{A})\end{array}$ & & 1 & 8 & & & & \\
\hline $\begin{array}{l}\text { Kemamp } \\
\text { uan } \\
\text { Berpikir } \\
\text { Kritis (B) }\end{array}$ & 1 & $\begin{array}{c}16,5 \\
3\end{array}$ & 5,44 & 0,457 & & 4,15 & 7,50 \\
\hline Interaksi & 1 & $\begin{array}{c}765, \\
44\end{array}$ & $\begin{array}{c}765, \\
44\end{array}$ & 64,308 & $* *$ & 4,15 & 7,50 \\
\hline Dalam & 32 & $\begin{array}{c}380, \\
89\end{array}$ & $\begin{array}{c}11,9 \\
0\end{array}$ & & & & \\
\hline $\begin{array}{l}\text { Total } \\
\text { Direduksi }\end{array}$ & 35 & $\begin{array}{c}1238 \\
, 89\end{array}$ & & & & & \\
\hline
\end{tabular}

Berdasarkan tabel uji ANAVA maka hipotesis pertama, yakni hasil belajar sejarah siswa yang menggunakan model pembelajaran integratif (A1) lebih tinggi dari hasil belajar siswa yang menggunakan model pembelajaran kooperatif (A2) $\left(\mathrm{H}_{0}: \mu\right.$ $\left.A_{1} \leq \mu A_{2} ; H_{1}: \mu A_{1}>\mu A_{2}\right)$. Berdasarkan hasil perhitungan diperoleh data $F_{\text {hitung }}$ untuk model pembelajaran memiliki skor 7.319, dengan skor $F_{\text {tabel }} 4.15$ pada taraf nyatanya $\alpha=0,05$. Sehingga dapat dibuktikan bahwa nilai $F_{\text {hitung }}>F_{\text {tabel }}$ artinya yaitu terdapat perbedaan hasil belajar sejarah antara siswa yang diberikan perlakuan model pembelajaran Integratif 
dibandingkan dengan siswa yang diberikan perlakuan model pembelajaran kooperatif. Berdasarkan pada rata-rata hasil belajar sejarah kelompok yang menggunakan model pembelajaran Integratif (A1) memiliki skor 27.11, sedangkan kelompok yang menggunakan model pembelajaran kooperatif (A2) memiliki skor 24,00, terbukti bahwa rata-rata kelompok A1 lebih tinggi dari kelompok $\mathrm{A} 2$ atau $\mu \mathrm{A}_{1}>\mu \mathrm{A}_{2}$. Maka uji hipotesis pertama membuktikan bahwa $\mathrm{H}_{1}$ diterima dan $\mathrm{H}_{0}$ ditolak.

Pengujian hipotesis kedua menunjukkan terdapat pengaruh interaksi antara penggunaan model pembelajaran dan kemampuan berpikir kritis terhadap hasil belajar sejarah siswa. Hipotesis statistik dirumuskan sebagai berikut:

$\left(\mathrm{H}_{0}\right.$ : INT. $A \times B=0 ; \mathrm{H}_{1}$ : INT. $\left.A \times B \neq 0\right)$. Hasil perhitungan ANAVA menunjukkan bawa interaksi memiliki skor $\mathrm{F}_{\text {hitung }}=$ 64,308 dengan skor $F_{\text {tabel }}=4,15$ pada taraf nyata $\alpha=0,0$. Maka terdapat interaksi antara penggunaan model pembelajaran dan kemampuan berpikir kritis terhadap hasil belajar sejarah siswa sangat signifikan.

Adapun gambar grafik interaksi antara model pembelajaran dengan kemampuan berpikir kritis terhadap hasil belajar sejarah siswa di SMA Negeri 13 Bekasi sebagai berikut:

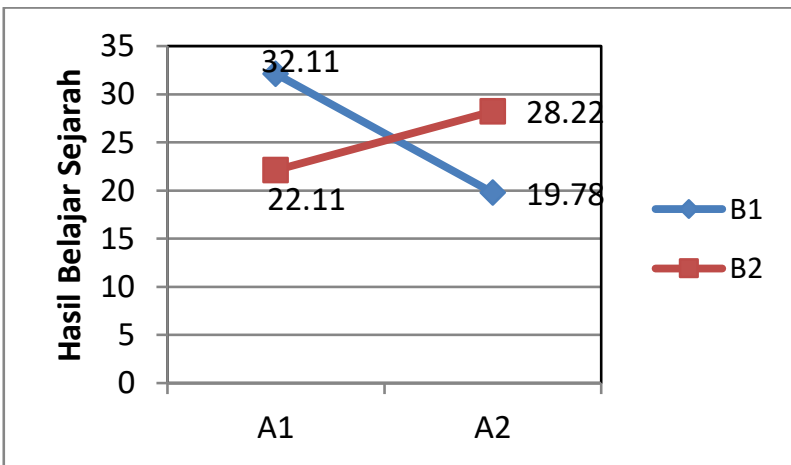

Gambar 1. Grafik interaksi antara model pembelajaran, kemampuan berpikir kritis dan hasil belajar sejarah

Hipotesis ketiga yakni hasil belajar sejarah siswa yang menggunakan model pembelajaran integratif lebih tinggi dari siswa yang menggunakan model pembelajaran kooperatif pada siswa yang memiliki kemampuan berpikir kritis tinggi
$\left(\mathrm{H}_{0}: \mu \mathrm{A}_{1} \mathrm{~B}_{1} \leq \mu \mathrm{A}_{2} \mathrm{~B}_{1} ; \mathrm{H}_{1}: \mu \mathrm{A}_{1} \mathrm{~B}_{1}>\mu \mathrm{A}_{2} \mathrm{~B}_{1}\right.$ ). Maka pengujian hipotesis ketiga dilanjutkan dengan Uji Tuckey untuk menguji taraf signifikannya. Setelah dilakukan pengujian maka diperoleh keterangan sebagai berikut:

\begin{tabular}{|c|c|c|}
\hline $\begin{array}{c}\text { Kelompok yang } \\
\text { dibandingkan }\end{array}$ & $Q_{\text {hitung }}$ & $\begin{array}{c}Q_{\text {tabel }} \\
\alpha=0,05\end{array}$ \\
\hline $\begin{array}{l}\text { A1B1 dan } \\
\text { A2B1 }\end{array}$ & 10,72 & 4,04 \\
\hline
\end{tabular}

Hasil tersebut menunjukan bahwa skor Qhitung lebih besar dari $Q_{\text {tabel }}$ pada taraf nyata $\alpha=0,05$, maka dapat disimpulkan bahwa terdapat perbedaan yang signifikan antara rata-rata hasil belajar sejarah pada siswa yang memiliki kemampuan berpikir kritis tinggi yang menggunakan model pembelajaran integratif (A1B1) dengan yang menggunakan model pembelajaran kooperatif (A2B1). Sehingga dapat dibuktikan juga bahwa rata-rata A1B1 yakni 32,11 lebih besar rata A2B1 yakni 19,78. Dari data tersebut, maka hipotesis ketiga dapat dibuktikan yakni $\mathrm{H}_{1}$ diterima dan $\mathrm{H}_{0}$ ditolak.

Hasil hipotesis keempat yakni hasil belajar sejarah siswa yang menggunakan model pembelajaran integratif lebih rendah dari siswa yang menggunakan model pembelajaran kooperatif pada siswa yang memiliki kemampuan berpikir kritis rendah $\left(\mathrm{H}_{0}: \mu \quad \mathrm{A}_{1} \mathrm{~B}_{2} \geq \mu \quad \mathrm{A}_{2} \mathrm{~B}_{2} ; \mathrm{H}_{1}: \mu \quad \mathrm{A}_{1} \mathrm{~B}_{2}<\mu\right.$ $\mathrm{A}_{2} \mathrm{~B}_{2}$ ). Setelah dilakukan pengujian dengan Uji Tuckey maka diperoleh keterangan sebagai berikut:

Tabel 4. Rangkuman Hasil Uji Tuckey Hipotesis Keempat

\begin{tabular}{ccc}
\hline $\begin{array}{c}\text { Kelompok yang } \\
\text { dibandingkan }\end{array}$ & Qhitung & $\begin{array}{c}\text {Q }_{\text {tabel }} \\
\alpha=0,05\end{array}$ \\
\hline A1B2 dan A2B2 & 5,31 & 4,04 \\
\hline
\end{tabular}

Hasil tersebut menunjukan bahwa skor $Q_{\text {hitung }}$ lebih besar dari $Q_{\text {tabel }}$ pada taraf nyata $\alpha=0,05$. Sehingga dapat disimpulkan bahwa terdapat perbedaan yang signifikan antara rata-rata hasil belajar sejarah pada 
siswa yang memiliki kemampuan berpikir kritis rendah dan menggunakan model pembelajaran integratif (A1B2) dengan yang menggunakan model pembelajaran kooperatif (A2B2). Dengan demikian, dapat dibuktikan juga bahwa rata-rata A1B2 adalah 22,11 lebih rendah dari ratarata $A_{2} B_{2}$ adalah 28.22, sehingga hipotesis keempat dapat dibuktikan yakni $\mathrm{H}_{1}$ diterima dan $\mathrm{H}_{0}$ ditolak.

\section{Pembahasan}

Penelitian yang dilakukan oleh Lis Suswati (2015) tentang "Pengaruh Integrative Learning terhadap Kemampuan Berpikir Kritis dan Penguasaan Konsep Fisika Siswa" memberikan hasil yang relevan dengan hasil penelitian ini. Hasil penelitian Lis Suswati secara keseluruhan menunjukkan bahwa terdapat perbedaan penguasaan konsep dan kemampuan berpikir kritis siswa yang belajar dengan integrative learning dan guide inquiry.

Juga, penelitian yang dilakukan oleh Dawit T. Tiruneh, An Verburgh \& Jan Elen (2014) yang berjudul tentang "Effectiveness of Critical Thinking Instructions in Higher Education: A Systematic Review of Intervention Studies" memberikan hasil yang relevan. Hasil penelitian Tiruneh, Verburgh, \& Elen menunjukkan bahwa keefektifan instruksi berpikir kritis dipengaruhi oleh kondisi lingkungan instruksional yang terdiri dari variabel strategi pengajaran dan pendekatan instruksional berpikir kritis dan variabel siswa. Sedangkan temuan secara keseluruhan menunjukkan bahwa terjadi pergeseran instruksi berpikir kritis di dalam disiplin akademis, namun gagal antara strategi instruksional yang efektif dalam membina dan menstransfer keterampilan berpikir kritis.

Penelitian relevan lain yaitu yang dilakukan oleh Iin Iryance (2014) tentang "Pengaruh Metode Pembelajaran dan Berpikir Kritis terhadap Hasil Belajar Sejarah Siswa SMA Kesatuan Bogor". Hasil penelitian secara keseluruhan menunjukkan bahwa metode pembelajaran dan kemampuan berpikir kritis terhadap hasil belajar sejarah siswa memberikan hasil yang lebih tinggi dengan menggunakan metode pembelajaran
PjBL daripada metode pembelajaran konvensional. Maka dapat disimpulkan untuk meningkatkan hasil belajar siswa yang memiliki kemampuan berpikir kritis tinggi dapat dilakukan dengan menggunakan metode PjBL.

Hasil pengujian hipotesis pertama menunjukkan bahwa hasil belajar siswa yang diberikan model pembelajaran integratif lebih tinggi dari hasil belajar sejarah siswa yang diberikan model pembelajaran kooperatif. Model pembelajaran integratif merupakan pembelajaran lebih mampu meningkatkan kemampuan berpikir kritis siswa secara aktif sehingga membangun pemahaman pengetahuan sendiri melalui proses integratif. Dengan pembelajaran integatif, siswa menjadi terlatih dalam menemukan dan memahami hubungan dalam bangunan sistematis pengetahuan, topik yang mengkombinasikan fakta, konsep, generalisasi di dalam satu matriks.

Proses pembelajaran yang menggunakan model pembelajaran integratif dianggap lebih mampu meningkatkan kemampuan berpikir kritis siswa dibandingkan dengan pembelajaran kooperatif. Pembelajaran kooperatif merupakan pembelajaran yang biasanya guru sebagai pembimbing siswa. Pembelajaran kooperatif berpusat pada guru dan siswa dalam mengolah informasi materi sesuai dengan struktur. Pembelajaran kooperatif hanya menuntut siswa untuk bekerjasama dan memecahkan suatu masalah melalui interaksi sosial dengan teman sebayanya. Penerapan kedua model pembelajaran ini akan menghasilkan hasil belajar yang berbeda karena kecenderungan yang muncul dari model pembelajaran integratif adalah siswa dapat membangun pengetahuan sendiri dengan memanfaatkan sumber belajar dengan baik dan mengolah informasi peristiwa sejarah penuh dengan makna.

Hasil pengujian hipotesis kedua menunjukkan bahwa terdapat pengaruh interaksi antara penggunaan model pembelajaran dengan kemampuan berpikir kritis siswa terhadap hasil belajar sejarah. Kedua interaksi yang terjadi mempengaruhi hasil belajar, namun pengaruh tersebut tergantung variabel bebas, seperti model pembelajaran yang dipadukan dengan kemampuan berpikir 
kritis siswa. Ketepatan dalam pemilihan model pembelajaran akan menghasilkan pembelajaran yang inovatif dan tujuan pembelajaran yang jelas. Dalam proses pembelajaran yang lebih mengutamakan informasi dan kemampuan berpikir kritis siswa mampu membangun pemahaman mendalam tentang materi sejarah untuk menumbuhkan nilai-nilai kesadaran sejarah bukan menghafal materi.

Hasil pengujian hipotesis ketiga menunjukkan bahwa hasil belajar sejarah siswa yang memiliki kemampuan berpikir kritis tinggi dan diberikan model pembelajaran integratif lebih tinggi dari siswa yang diberikan model pembelajaran kooperatif. Siswa dengan kemampuan berpikir kritis yang diberikan model pembelajaran integratif lebih tertantang selama proses pembelajaran sehingga mampu membangun pemahaman konsep-konsep baru melalui matriks yang dibuat guru. Secara teoretik model pembelajaran integratif sangat sesuai jika diberikan pada siswa dengan kemampuan berpikir kritis tinggi.

Keterlibatan interaksi siswa dalam proses pembelajaran sangat tinggi karena pembelajaran tersebut melatih daya keterampilan berpikir kritis sehingga mudah bagi siswa untuk dapat mengembangkan analisis dalam suatu hipotesis. Berbeda dengan pembelajaran kooperatif, hanya beberapa siswa yang memiliki kemampuan berpikir kritis tinggi mengalami kesulitan untuk menggunakan keterampilan berpikir tetapi berorientasi menghafal. Semakin banyak informasi yang disampaikan guru mengakibatkan pasifnya siswa dalam mengolah informasi, pertanyaan dan konsentrasi siswa akan menurun. Dapat disimpulkan bahwa siswa yang berkemampuan berpikir kritis tinggi lebih tepat diberikan model pembelajaran integratif daripada model pembelajaran kooperatif.

Model integratif dapat diartikan sebagai sebuah model pengajaran atau intruksional untuk membantu siswa mengembangkan pemahaman secara mendalam tentang bangunan pengetahuan sistematis sambil secara bersamaan melatih keterampilan berfikir kritis mereka. Adapun keberhasilan yang diperoleh selama siklus kedua ini adalah kemampuan siswa dalam proses belajar mengajar sudah mengarah kepembelajaran bermakna dengan model integratif. Siswa mampu mengamati, menganalisis, serta generalisasi materi hal ini dapat dilihat dari hasil belajar (Akbar, 2015).

Hasil pengujian hipotesis keempat menunjukkan bahwa hasil belajar sejarah siswa yang memiliki kemampuan berpikir kritis rendah dan diberikan model pembelajaran integratif lebih rendah dari siswa yang diberikan model pembelajaran kooperatif. Pembelajaran integratif menekankan pada keterampilan berpikir siswa dan pembelajaran kooperatif menekankan pada informasi yang disampaikan secara langsung oleh guru. Siswa dengan kemampuan berpikir kritis rendah cenderung kurang tertarik dengan kegiatan yang berorientasi pada berpikir untuk menyelesaikan masalah sehingga siswa kurang aktif komunikatif dalam bertanya di dalam proses pembelajaran. Model pembelajaran kooperatif tidak menuntut siswa untuk lebih aktif dan unggul sehingga siswa dengan kemampuan berpikir kritis rendah lebih suka menerima informasi sumber belajar dari teman kelompoknya dan pengarahan langsung dari guru.

Pembelajaran kooperatif dapat membantu siswa untuk bekerja sama dalam sebuah kelompok yang terdiri dari empat orang dalam satu kelompok, tujuannya untuk menguasai materi yang disampaikan guru. Siswa tidak perlu membangun pemahaman pengetahuannya sendiri tetapi dapat menerima informasi atau materi dari guru. Keberhasilan dalam proses pembelajaran kooperatif, tergantung pada guru yang menyampaikan informasi materi sehingga siswa yang kemampuan berpikir kritis rendah dapat mengikuti proses pembelajaran secara maksimal. Keberagaman dan karakteristik siswa di kelas dapat mempengaruhi model pembelajaran dan hasil belajar siswa sehingga penting bagi guru untuk memfasilistasi proses pembelajaran sehingga siswa mampu meningkatkan hasil belajar.

\section{PENUTUP}

Hasil belajar siswa yang diberikan model pembelajaran integratif lebih tinggi 
dari pada siswa yang memperoleh model pembelajaran kooperatif. Kemudian terdapat pengaruh pada interaksi antara model pembelajaran dan kemampuan berpikir kritis siswa terhadap hasil belajar sejarah. Hasil belajar sejarah siswa yang memiliki kemampuan berpikir kritis tinggi dan diberikan model pembelajaran integratif lebih tinggi dari yang diberikan model pembelajaran kooperatif dan hasil belajar sejarah siswa yang memiliki kemampuan berpikir kritis rendah dan diberikan model pembelajaran integratif lebih rendah dari yang diberikan model pembelajaran kooperatif.

Penelitian ini berimplikasi pada pemilihan model pembelajaran sejarah. Model pembelajaran integratif menjadi sangat cocok digunakan dalam pembelajaran sejarah karena dapat meningkatkan hasil belajar sejarah. Melalui model pembelajaran integratif siswa dibiasakan untuk dapat menganalisis masalah, mengumpulkan dan mengolah data, aktif dalam interaksi, dan memiliki kemampuan untuk membangun pengetahuan secara individu. Implikasi yang kedua adalah penggunaan model pembelajaran integratif dapat meningkatkan analisis hasil belajar sejarah dan melatih kemampuan berpikir kritis siswa. Kemudian, siswa yang memiliki tingkat kemampuan berpikir kritis yang tinggi lebih tepat menggunakan model pembelajaran integratif karena mampu mengembangkan secara optimal kemampuan berpikir kritisnya serta kemampuan dalam mengolah informasi. Lebih lanjut, siswa yang memiliki tingkat kemampuan berpikir kritis yang rendah lebih tepat apabila diterapkan model pembelajaran kooperatif, agar proses pencapaian hasil belajar lebih maksimal.

\section{UCAPAN TERIMA KASIH}

Terima kasih kepada Dosen Pemimbing I Dr. Sarkadi, M.Si dan Dosen Pembing II selaku Kaprodi Pascasarjana Pendidikan Sejarah Dr.Kurniawati, M.Si.

\section{DAFTAR PUSTAKA}

Akbar, N. S. (2015). "Penerapan pembelajaran integratif untuk meningkatkan hasil belajar melaksanakan pekerjaan dasar-dasar survey dan pemetaan". Unimed Jurnal Education Building: Vol 1, No. 2,12. Iryance, Iin. (2014)."Pengaruh Metode Pembelajaran dan Berpikir Kritis Terhadap Hasil Belajar Sejarah Siswa SMA Kesatuan Bogor", Jurnal Pendidikan Sejarah, Vol.3 No. $1 \quad$ Januari-Juni.

Subakti. (2010). Y.R. Paradigma Pembelajaran Berbasis

Konstruktivisme. Yogyakarta: SPPS, Vol.24, No. 1. April

Sugiyono. (2017). Statistiska Untuk Penelitian. Bandung: Alfabeta.

Suswati, Lis, dkk. (2015). Pengaruh Integrative Learning Terhadap Kemampuan Berpikir Kritis dan Penguasaan Konsep Fisika Siswa. Jurnal Pendidikan Sains, Vol. 3 No. 2, Juni.

Tiruneh, Dawit T., dkk. (2014) "Effectiveness of Critical Thinking Instructions in Higher Education: A Systematic Review of Intervention Studies", International Journal of Teaching and Learning in Higher Education. 